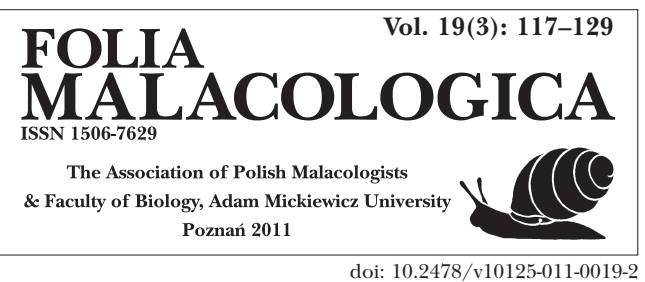

\title{
PSEUDAMNICOLA EXILIS (FRAUENFELD, 1863) IN SOUTHERN GREECE: A REMNANT OF A FLOCK OF SPECIES (RISSOOIDEA: HYDROBIIDAE)?
}

\author{
Magdalena SZAROWSKa, ANDRZEJ FALNIOWSKI
}

\begin{abstract}
${ }^{1}$ Department of Malacology Institute of Zoology, Jagiellonian University, Gronostajowa 9, 30-387 Kraków, Poland (afalniowski@o2.pl, andrzej.falniowski@uj.edu.pl)

ABSTRACT: The morphology of shell, penis, and female reproductive organs was studied in five populations of Pseudamnicola exilis (Frauenfeld) from southern Peloponnese and Kithira Island (Greece). No interpopulation differences were found in any of the characters. Thirty eight sequences of mitochondrial cytochrome oxidase subunit I (COI) and nuclear ribosomal 18S RNA genes were analysed. In COI 19 haplotypes, high haplotypy diversity, low nucleotide diversity in each population, and restricted gene flow between populations were found. NCA indicated allopatric fragmentation for all populations, and long-distance colonisation and/or past fragmentation for populations 4 and 5. Mismatch distribution in the most polymorphic population 4 reflected a bottleneck followed by population growth. The values of K2P interpopulation distances, though relatively low, pointed to congeneric distinct species within the Rissooidea. The monophyly of Pseudamnicola/Adrioinsulana clade was confirmed. Most probably the studied populations of Pseudamnicola were part of a flock of vicariant species little differentiated in morphology and ecology, many of which must have disappeared due to human impact.
\end{abstract}

KEY WORDS: Pseudamnicola, morphology, COI, 18S rRNA, population, diversity, gene flow, phylogeny

\section{INTRODUCTION}

The genus Pseudamnicola Paulucci, 1878, with its type species Paludina macrostoma Küster, 1853 (KABAT \& HERSHLER 1993), once contained dozens of taxa. The representatives of all those taxa shared a small, ovate-conical, umbilicate shell, and a radula (THIELE 1929) the characteristics of which could be ascribed to many rissooid gastropods. The species assigned to this genus were known from the British Isles, the Netherlands, and Spain, through France, Italy and the Balkans, to Romania and Cyprus. Anatomical studies, most of which considered the reproductive organs, proved that "Pseudamnicola" was a collection of several evolutionary lineages whose relationships were not necessarily close (RADOMAN 1973, 1983, GIUSTI \& PEZZOLI 1980). These are now assigned to various genera such as Mercuria, Sadleriana, Orientalina, Grossuana, Polinskiola, Ohridohauffenia, Ohrigocea, Dolapia, Graecorientalia, Belgrandia, Lyhnidia, Adriohydrobia, etc. (WAGNER 1927, RADOMAN 1973, 1983, GLÖER 2002). Within the literature on the
Greek malacofauna (see BUTOT \& WELTER-SCHULTES 1994) there are some reports on the occurrence of Pseudamnicola. However, most of these reports, as not based on anatomy, are not reliable. Shell characters are often positively misleading within the Rissooidea (e.g. SZAROWSKA \& WILKE 2004).

BOETERS (1971) described the anatomy of Pseudamnicola lucensis (Issel, 1866) from the type locality in Italy. RADOMAN (1972) described the anatomy of $P$. conovula (Frauenfeld, 1863) from the Pag Island in Croatia; next he described a new monotypic genus Adrioinsulana for that species (RADOMAN 1978). SZAROWSKA et al. (2006) did not confirm the distinctness of the genus Adrioinsulana. According to RADOMAN (1983, 1985) not all the species of Pseudamnicola mentioned from the Balkans (the territory of the former Yugoslavia, in particular) belong to this genus. It must be noted that even with Adrioinsulana conovula as a representative of Pseudamnicola, the range of this genus in the former 
Yugoslavia is restricted to a few islands and the adjacent mainland in northern Croatia. Thus the known range of Pseudamnicola is not continuous. The Italian and West European taxa are separated form the Greek ones.

GiUsti \& PEZzOLI (1980) distinguished three species of Pseudamnicola in Italy: P. lucensis, P. moussoni (Calcara, 1841) and P. conovula, and illustrated their reproductive organs. SCHÜTT (1980) distinguished seven taxa of Pseudamnicola in Greece. Out of these, he assigned four species to the islands, and two species and one subspecies to continental Greece and Evvoia. However, he distinguished all those taxa based on the shell alone, and only for two species he illustrated (not described) the anatomy. Moreover, the drawings are of poor quality (figs 4-5 in SCHÜTT 1980). Following strictly the geographical concept of speciation, like in the case of his "Belgrandiella", "Semisalsa" or Bythinella, in Pseudamnicola he divided the territory into separate parts that harboured one "species" of the genus each. Accordingly (SCHÜTT 1980), the southern part of Peloponnese was inhabited by $P$. exilis (Frauenfeld, 1863). FALNIOWSKI \& SZAROWSKA (1995a, b) described the shell surface and internal structure in Pseudamnicola cf. moussoni $[=$

\section{MATERIAL AND METHODS}

The material was collected in 2007 and 2009, from five localities in southern Greece (Fig. 1):

1 - near Agio Theodori, between Belitseika and Koutiveika, western part of N. Taigetos Mts, Peloponnese; $36^{\circ} 56^{\prime} 55.6^{\prime \prime} \mathrm{N}, 2^{\circ} 10^{\prime} 0.7$ ”E, $238 \mathrm{~m}$ a.s.l.;

2 - W of Nomia, Nisis Monemvasia, SE. Peloponnese; $36^{\circ} 39^{\prime} 18.1^{\prime \prime} \mathrm{N}, 2^{\circ} 59^{\prime} 43.6 ” \mathrm{E}, 70 \mathrm{~m}$ a.s.l.;

3 - W of Ayios Niron, Nisis Sfondili, SE. Peloponnese; $36^{\circ} 27^{\prime} 09.2^{\prime \prime} \mathrm{N}, 23^{\circ} 07^{\prime} 07.1 ” \mathrm{E}, 87 \mathrm{~m}$ a.s.l.;

4 - spring at Karavas, $\mathrm{N}$ of Kithira Island; $36^{\circ} 20^{\prime} 50.4^{\prime \prime} \mathrm{N}, 2^{\circ} 56^{\prime} 57.8^{\prime \prime} \mathrm{E}, 66 \mathrm{~m}$ a.s.l.;

5 - spring at Viaradika, central Kithira Island; $36^{\circ} 14^{\prime} 24^{\prime \prime} \mathrm{N}, 2^{\circ} 59^{\prime} 48.6 ” \mathrm{E}, 203 \mathrm{~m}$ a.s.l.

The snails were collected with a sieve, or by hand. For molecular studies they were washed twice in $80 \%$ ethanol and left to stand in it for ca. 12 hours. Afterwards, the ethanol was changed twice in 24 hours and finally, after a few days, the $80 \%$ solution was exchanged for a $96 \%$ one, stored at $-20^{\circ} \mathrm{C}$.

For morphological studies the material was fixed in $4 \%$ formalin and stored in $80 \%$ ethanol. The shells were cleaned in an ultrasonic cleaner and photographed with a CANON EOS 50D digital camera. Ten adults (five males, five females) out of each population were dissected using a NIKON SMZ-U stereomicroscope with a NIKON drawing apparatus, and a NIKON DS- 5 digital camera. In each male or female, the penis or the pallial section of the female reproductive organs was drawn, accordingly.
P. macrostoma (Küster, 1853): SzAROWSKA et al. (2006)] from Vravrona. The shell, radula and anatomy of $P$. macrostoma from two localities in Attica, and $P$. negropontina (Clessin, 1878) from Evvoia were described by SZAROWSKA et al. (2006). Based on cytochrome oxidase subunit I (COI) of mtDNA, the latter study confirmed that the Greek $P$. negropontina belonged to the same genus as the Italian P. lucensis (SZAROWSKA et al. 2006).

During our extensive sampling of springs in continental Greece (including the islands Lefkas, Evvoia and Kithira) in 2003, 2007, 2008 and 2009, we found that many of the Pseudamnicola localities known from the literature had been destroyed (SZAROWSKA \& FALNIOWSKI 2004, SZAROWSKA 2006, SZAROWSKA, et al. 2006). The snails became scarce: we found Pseudamnicola only at five localities in the southern Peloponnese and Kithira. All the localities were within the distribution range of $P$. exilis.

The aims of this study were as follows: (1) to check morphological characters of the shell and reproductive organs of $P$. exilis; (2) based on mitochondrial COI and nuclear $18 \mathrm{~S}$ rRNA sequences, to infer the phylogenetic relationships and intra- and interpopulation diversity of the five populations.

DNA was extracted from foot tissue of each snail. The tissue was hydrated in TE buffer $(3 \times 10 \mathrm{~min}$.) and total genomic DNA was extracted with the SHERLOCK extracting kit (A\&A Biotechnology). The final product was dissolved in $20 \mu \mathrm{l}$ TE buffer. The PCR reaction was performed with the following primers: LCOI490 (5'-GGTCAACAAATCATAAAGATATTG G-3') and COR722b (5'-TAAACTTCAGGGTGACCAA AAAATYA-3') for the cytochrome oxidase subunit I

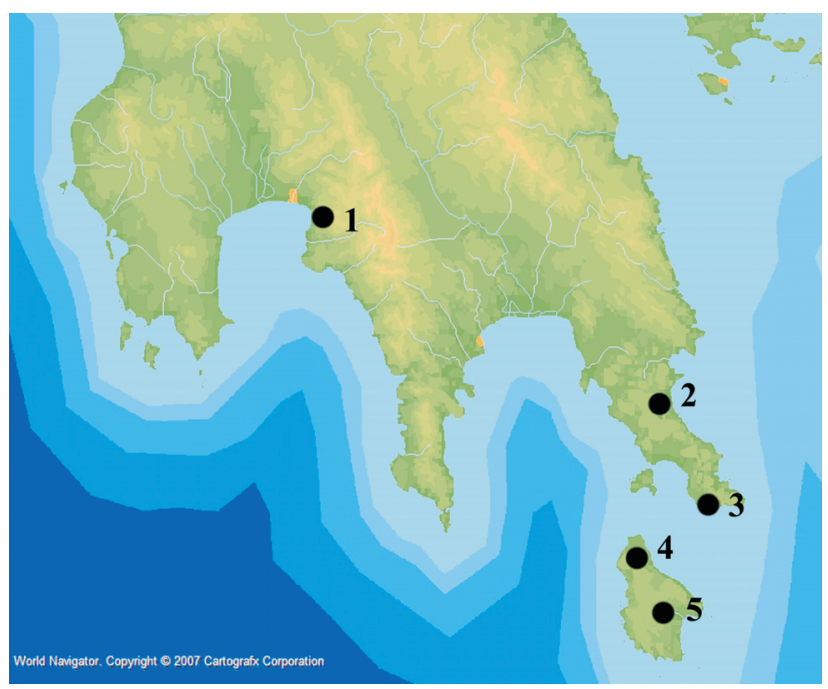

Fig. 1. Sampling localities of Pseudamnicola. Figure made using Cartografx Professional Software 
(COI) mitochondrial gene (FOLMER et al. 1994), and SWAM18SF1 (5'-GAATGGCTCATTAAATCAGTCGA GGTTCCTTAGATGATCCAAATC-3'), and SWAM 18SR1 (5'-ATCCTCGTTAAAGGGTTTAAAGTGT ACTCATTCCAATTACGGAGC-3') for the 18S rRNA nuclear gene (18S) (PALUMBI 1996). The PCR conditions were as follows: COI: initial denaturation step of $4 \mathrm{~min}$. at $94^{\circ} \mathrm{C}$, followed by 35 cycles of $1 \mathrm{~min}$. at $94^{\circ} \mathrm{C}, 1 \mathrm{~min}$. at $55^{\circ} \mathrm{C}, 2 \mathrm{~min}$. at $72^{\circ} \mathrm{C}$, and a final extension of $4 \mathrm{~min}$. at $72^{\circ} \mathrm{C} ; 18 \mathrm{~S}$ : initial denaturation step of $4 \mathrm{~min}$. at $94^{\circ} \mathrm{C}$, followed by 40 cycles of $45 \mathrm{~s}$ at $94^{\circ} \mathrm{C}, 45 \mathrm{~s}$ at $51^{\circ} \mathrm{C}, 2 \mathrm{~min}$. at $72^{\circ} \mathrm{C}$. After all cycles were completed, an additional elongation step of 4 min. at $72^{\circ} \mathrm{C}$ was performed. The total volume of each PCR reaction mixture was $50 \mu \mathrm{l}$. To check the quality of the PCR products $10 \mu$ l of the PCR product was run on $1 \%$ agarose gel. The PCR product was purified using Clean-Up columns (A\&A Biotechnology) and the purified PCR product was amplified in both directions (HILlis et al. 1996) using BigDye Terminator v3.1 (Applied Biosystems), following the manufacturer's protocol and with the primers described above. The sequencing reaction products were purified using ExTerminator Columns (A\&A Biotechnology); DNA sequences then underwent electrophoresis on an ABI Prism sequencer. All the sequences were deposited in GenBank.

In the phylogeny reconstruction, sequences of nine rissooid taxa from GenBank were used (Table 1). The COI sequences were aligned by eye using BioEdit 5.0.0 (HALL 1999) and edited with MACCLADE 4.05 (MADDISON \& MADDISON 2002). For 18S, an initial alignment was performed using CLUSTALX 1.82 (THOMPSON et al. 1997) and edited with MACCLADE. For COI haplotype diversity $h$ and nucleotide diversity $\pi$ with DNASP (ROZAS et al. 2003), and $\theta_{S}$ (WATTERSON 1975, TAJIMA 1989) and $\theta_{\pi}$ (TAJIMA 1983) with Arlequin 3.1 (EXCOFFIER et al. 2005), were computed. To estimate gene flow between the populations, AMOVA (EXCOFFIER et al. 1992, WEIR 1996) was calculated with estimates of gene flow with Arlequin 3.1 (EXCOFFIER et al. 2005): $\mathrm{F}_{\mathrm{st}} ; \mathrm{Nm}$ and coancestry coefficient (REYNOLDS et al. 1983); significance tests were run with 20,000 permutations. Mismatch distribution (ROGERS \& HARPENDING 1992, HARPENDING 1994, ROGERS 1995, ROGERS \& JORDEY 1995, SCHNEIDER \& EXCOFFIER 1999, HARPENDING \& ROGERS 2000, EXCOFFIER 2004) analyses were conducted using DnaSP 4.0 (ROZAS et al. 2003) and Arlequin (EXCOFFIER et al 2005), with 20,000 permutations.

We inferred haplotype networks for COI with TCS 1.21 (CLEMENT et al. 2000), with the connection limit excluding homoplastic changes conventionally set to $95 \%$. There is no reliable technique of analysing phylogeographical data (KNOWLES \& MADDISON 2002). Nested clade analysis (NCA) introduced by TEMPLETON (TEMPLETON et al. 1987, 1992, TEMPLETON \& SING 1993, TEMPLETON 2008) lacks statistical inference (KNOWLES \& MADDISON 2002), simulations proved that it often does not find a realistic interpretation of the data, although those simulations are also criticised as not necessarily realistic (PANCHAL \& BEAUMONT 2007, PETIT 2007, 2008, GARRICK et al. 2008, TEMPLETON 2008). Thus we inferred the NCA approach with the ANeCA (automation of nested clade phylogeographical analysis: PANCHAL 2007), implementing the construction of haplotype networks (with TCS), nesting of clades, calculation of summary statistics with tests of siginificance applying GeoDis 2.5 (POSADA et al. 2000 ), and the interpretation of results with an inference key (TEMPLETON 2008). To carry out tests of significance, 10,000 random permutations of geographical locations of individuals were run.

PAUP*4.0b10 (SWOFFORD 2002) was used to calculate K2P (KIMURA 1980) distances for the COI data. This distance is widely used in the literature for COI data, thus it is useful for comparisons of levels of differentiation.

Mutational saturation for the COI dataset was examined by plotting observed (uncorrected) pairwise distances ( $p$-distances) versus estimated distances using the maximum likelihood parameters chosen with Modeltest, as described below. Saturation was also examined, plotting the numbers of transitions and transversions for all the codon positions and separ-

Table 1. Taxa used for phylogenetic analyses, with their GenBank Accession Numbers and references

\begin{tabular}{llll}
\hline \multicolumn{1}{c}{ Species } & 18S GB\# & CO1 GB\# & \multicolumn{1}{c}{ References } \\
\hline Adriohydrobia gagatinella (Küster, 1852) & AF367657 & AF317881 & WILKE \& FALNIOWSKI (2001) \\
Adrioinsulana conovula (Frauenfeld, 1863) & AF367656 & AF367628 & WILKE et al. (2001) \\
Dianella thiesseana (Kobelt, 1878) & AY676125 & AY676127 & SZAROWSKA et al. (2005) \\
Hydrobia acuta (Draparnaud, 1805) & AF367680 & AF278808 & WILKE \& DAVIS (2000) \\
Pseudamnicola lucensis (Issel, 1866) & AF367687 & AF367651 & WILKE et al. (2001) \\
Pseudamnicola negropontina (Clessin, 1878) & & EF061915 & SZAROWSKA et al. (2006) \\
Pyrgula annulata (Linnaeus, 1767) & AY676124 & AY341258 & SZAROWSKA et al. (2005) \\
Rissoa labiosa (Montagu, 1803) & AY676126 & AY676128 & SZAROWSKA et al. (2005) \\
Ventrosia ventrosa (Montagu, 1803) & AF367681 & AF118335 & WILKE \& DAVIS (2000) \\
\hline
\end{tabular}


ately for the 3rd position against the percentage sequence divergence with DAMBE 5.2.9 (XIA 2000). We used DAMBE 5.2.9 also to perform saturation test of XIA et al. (2003).

For each maximum likelihood (ML) analysis, we used the best fit model of sequence evolution found by Modeltest v3.06 (POSADA \& CRANDALL 1998, POSADA 2003). Following the recommendations of POSADA \& BUCKLEY (2004) and SOBER (2002), the best model for each dataset was chosen using the Akaike Information Criterion (AKAIKE 1974). ML analyses were performed in PAUP*4.0b10 (SWOFFORD 2002), using a heuristic search strategy with stepwise addition of taxa, 10 random-sequence addition replicates, and tree-bisection-reconnection (TBR) branch swapping (SWOFFORD et al. 1996). Nodal support was estimated using the bootstrap approach (FELSENSTEIN 1985). Bootstrap values for ML trees were calculated using 2,000 bootstrap replicates, the "fast" heuristic search algorithm, and the same model parameters as for each ML analysis. The phylogeny was inferred separately for COI and 18S. Next, the partition homogeneity test (FARRIS et al. 1995) was performed (1,000 replicates) with PAUP*, to check whether the two genes could be analysed together. The maximum likelihood heuristic search strategy described above was then run for the combined molecular data.

\section{RESULTS}

\section{MORPHOLOGY}

The shells of the studied Pseudamnicola differed among populations in size but not in shape (Figs

2-14). The same concerns the penes (Figs 15-25). Simple (without lobes on the left edge) and massive, their vas deferens visible only in some specimens (Fig. 15), they did not differ among populations. Fig. 26

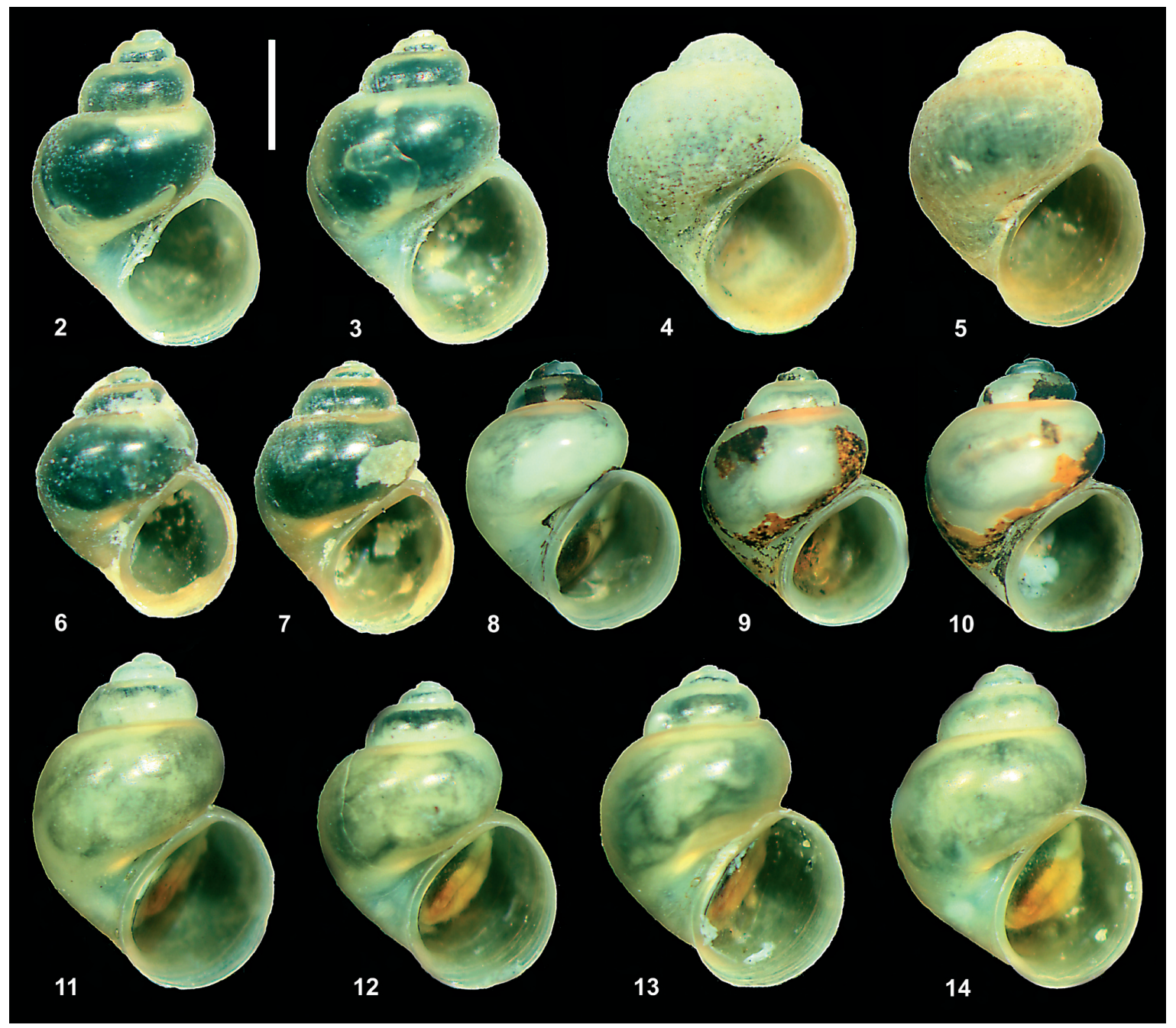

Figs 2-14. Shells of Pseudamnicola: 2-3 - locality 1, 4-5 - locality 3, 6-7 - locality 2, 8-10- locality 4, 11-14- locality 5. Scale bar $1 \mathrm{~mm}$ 


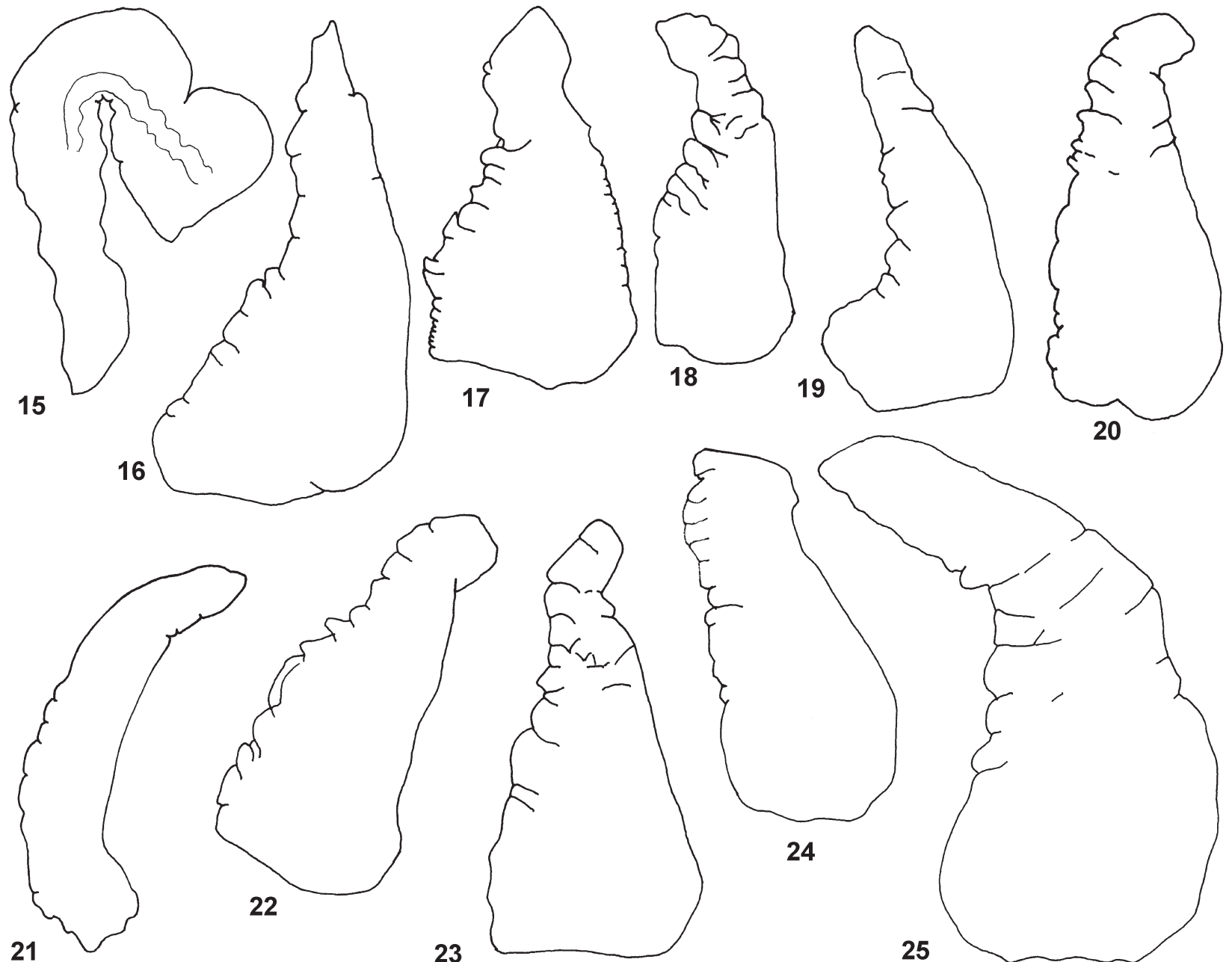

Figs 15-25. Penes of Pseudamnicola: 15-17 - locality 1, 18-19 - locality 2, 20-21 - locality 3, 22-23 - locality 4, 24-25 - locality 5

shows the pallial and renal section of the female reproductive organs with one seminal receptacle and bursa copulatrix, and a dark-pigmented spiral of the oviduct. Like in the shell and penis, there was no difference among populations in these organs.

Fig. 26. Renal and pallial section of female reproductive organs of Pseudamnicola from locality 1; abbreviations: bc - bursa copulatrix, cbc - duct of bursa copulatrix, dgp - gonopericardial duct, ga - albumen gland, gn - capsule gland, gp - gonoporus, ov - oviduct, ovl - coil (spiral) of (renal) ovi-

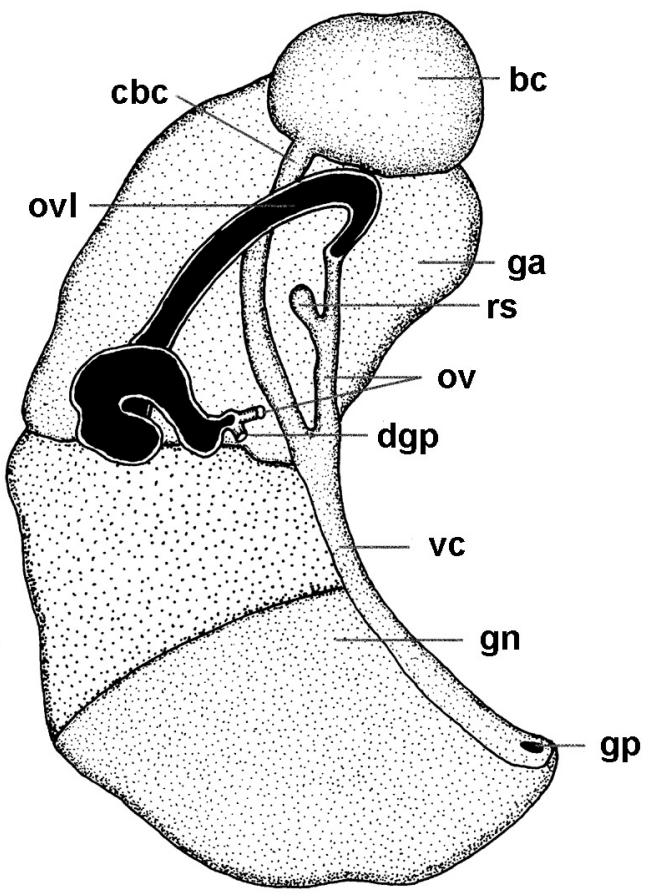
duct, rs - seminal receptacle, vc - ventral channel 


\section{MOLECULAR INTRA- AND INTERPOPULATION DIFFERENTIATION}

In total, 38 sequences of mitochondrial cytochrome oxidase subunit I (COI, GenBank Accession Numbers: JF921885-JF921922), and 38 sequences of nuclear ribosomal 18S RNA (GenBank Accession Numbers: JF921877-JF921884) genes were used for phylogeny reconstruction. COI was used for molecular genetic studies as well.

In COI, 19 haplotypes were found (Table 2): two in population 1 , eight in population 4 , and three in the remaining three populations. In all the populations high values of haplotype diversity $h$ and low values of nucleotide diversity $\pi$ were detected. The highest values of both parameters were found in population 4 , the smallest in population 1 , the same concerning both $\theta_{\mathrm{S}}$ and $\theta_{\pi}$ (Table 2 ).

The pairwise values of $\mathrm{F}_{\text {st }}$ (Table 3 ) were all statistically highly significant. The pairwise coancestry coefficients (Table 4) and inferred pairwise Nm estimates (Table 4) indicated, in general, low levels of gene flow between the studied populations of Pseudamnicola.

In population 4, which harboured eight haplotypes, mismatch distribution markedly differed from the expected one (Fig. 27), left-skewed and with three peaks. The haplotype networks of populations 1,2 and 3 consisted of 2-3 haplotypes each; they were not

Table 2. Intrapopulation genetic differentiation indices for the studied populations of Pseudamnicola from south Greece. Nnumber of specimens sequenced, $\mathrm{n}$ - number of haplotypes, $h$ - haplotype diversity, $\pi$ - nucleotide diversity

\begin{tabular}{ccccccc}
\hline Population & $\mathrm{N}$ & $\mathrm{n}$ & $h$ & $\pi$ & $\theta_{\mathrm{s}}$ & $\theta_{\pi}$ \\
\hline 1 & 8 & 2 & 0.25000 & 0.00078 & 0.77135 & 0.50000 \\
& & & \pm 0.180 & \pm 0.00057 & \pm 0.59339 & \pm 0.53730 \\
2 & 7 & 3 & 0.52381 & 0.00164 & 1.22449 & 1.04762 \\
& & & \pm 0.209 & \pm 0.00080 & \pm 0.83590 & \pm 0.89901 \\
3 & 6 & 3 & 0.73333 & 0.00146 & 0.87591 & 0.93333 \\
& & & \pm 0.155 & \pm 0.00081 & \pm 0.68388 & \pm 0.85201 \\
4 & 8 & & 1.00000 & 0.00834 & 3.85675 & 5.32143 \\
& & & \pm 0.063 & \pm 0.00100 & \pm 1.98624 & \pm 3.27238 \\
5 & & 3 & 0.66667 & 0.00209 & 1.10381 & 1.14196 \\
& & & \pm 0.105 & \pm 0.00036 & \pm 0.73845 & \pm 1.03240 \\
\hline \multirow{2}{*}{ all } & 38 & 19 & 0.93314 & 0.03842 & 1.56649 & 1.78887 \\
& & & \pm 0.019 & \pm 0.00259 & \pm 1.15631 & \pm 1.77989 \\
\hline
\end{tabular}

Table 3. Interpopulation differentiation in the five populations of Pseudamnicola from South Greece. Below diagonal: $\mathrm{F}_{\text {st }}$ values, above diagonal: $\mathrm{p}$ values of $\mathrm{F}_{\mathrm{st}}$, with standard deviations, computed with 20,000 permutations

\begin{tabular}{|c|c|c|c|c|c|}
\hline & 1 & 2 & 3 & 4 & 5 \\
\hline 1 & $* . * * * * *$ & $\begin{array}{c}0.00085 \\
\pm 0.00020\end{array}$ & $\begin{array}{c}0.00090 \\
\pm 0.00020\end{array}$ & $\begin{array}{r}0.00165 \\
\pm 0.00030\end{array}$ & $\begin{array}{r}0.00010 \\
\pm 0.00010\end{array}$ \\
\hline 2 & 0.53495 & $* . * * * * *$ & $\begin{array}{r}0.00449 \\
\pm 0.00050\end{array}$ & $\begin{array}{l}0.00280 \\
\pm 0.0003\end{array}$ & $\begin{array}{r}0.00230 \\
\pm 0.00030\end{array}$ \\
\hline 3 & 0.62063 & 0.37671 & $* . * * * * * *$ & $\begin{array}{l}0.00769 \\
\pm 0.0006\end{array}$ & $\begin{array}{r}0.00025 \\
\pm 0.00010\end{array}$ \\
\hline 4 & 0.37500 & 0.12528 & 0.23035 & $* . * * * * *$ & $\begin{array}{c}0.00934 \\
\pm 0.00070\end{array}$ \\
\hline 5 & 0.53282 & 0.30372 & 0.39923 & 0.17061 & $* * * * * *$ \\
\hline
\end{tabular}

Table 4. Interpopulation differentiation in the five populations of Pseudamnicola from South Greece. Below diagonal: pairwise coancestry coefficients $\left[\mathrm{t} / \mathrm{M}=-\ln \left(1-\mathrm{F}_{\mathrm{st}}\right)\right]$ (REYNOLDS et al. 1983); above diagonal: pairwise M (=Nm for haploid data)

\begin{tabular}{cccccc}
\hline & 1 & 2 & 3 & 4 & 5 \\
\hline 1 & $* . * * * * *$ & 0.43466 & 0.30563 & 0.83333 & 0.43840 \\
2 & 0.76562 & $* . * * * * *$ & 0.82727 & 3.49091 & 1.14623 \\
3 & 0.96924 & 0.47275 &.$* * * * * 23$ & 1.67059 & 0.75242 \\
4 & 0.47000 & 0.13386 & 0.26182 & $* . * * * *$ & 2.43066 \\
$\underline{5}$ & 0.76105 & 0.36201 & 0.50954 & 0.18707 & $* . * * * * *$ \\
\hline
\end{tabular}


connected between populations with an assumed level of $95 \%$ difference. Only the network for populations 4 and 5 from Kithira (Fig. 28) was complex. Nested clade analysis (NCA) together with inference key indicated allopatric fragmentation for total cladogram, and long-distance colonisation and/or past fragmenation for populations 4 and 5 .

The pairwise p-distances and $\mathrm{K} 2 \mathrm{P}$ distances among the five studied populations, and the other rissooid taxa considered, are listed in Table 5. The intrapopulation K2P distances varied from 0.00079 in population 1 to 0.00731 in population 4 (Table 5). The interpopulation K2P distances (Table 5) varied from 0.01882 (between populations 4 and 5) to 0.05568 (between populations 1 and 3). The K2P distances among the other Pseudamnicola and Adrioinsulana species (Table 5) ranged from 0.07561 to 0.09356 .

\section{MOLECULAR PHYLOGENY}

The plots of the observed (uncorrected) pairwise distances ( $p$-distances) versus estimated distances using the maximum likelihood parameters chosen with Modeltest showed no saturation within the studied sequences of Pseudamnicola and Adrioinsulana. Similar results were obtained by plotting the numbers of transitions and transversions for all the codon positions and separately for the 3rd position against the percentage sequence divergence with DAMBE, and saturation test of XIA et al. (2003).

The partition homogeneity test showed that the two genes could be analysed together.

For the combined data set Akaike Information Criterion (AIC) with ModelTest selected the model $\mathrm{HKY}+\mathrm{I}+\Gamma$, with base frequencies: $\mathrm{A}=0.2677, \mathrm{C}=0.2007$, $\mathrm{G}=0.2045, \mathrm{~T}=0.3270$; substitution model: $\mathrm{ti} / \mathrm{tv} \mathrm{ra}-$ tio=3.6876, proportion of invariable sites: $(\mathrm{I})=0.6602$, and $\Gamma$ distribution with the shape parameter $=0.6175$.

The inferred ML phylogeny (Fig. 29) based on combined data sets was similar to the one inferred with COI (not presented). The clade that clustered

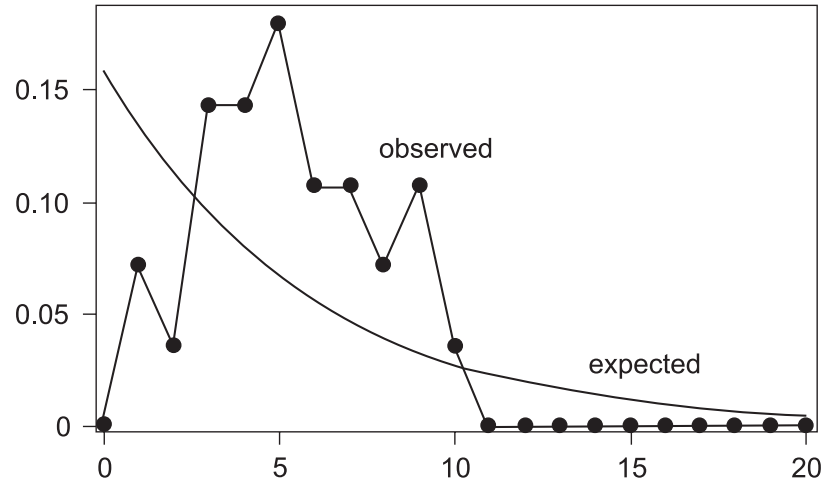

Fig. 27. Mismatch distribution for population 4: horizontal axis represents number of pairwise differences

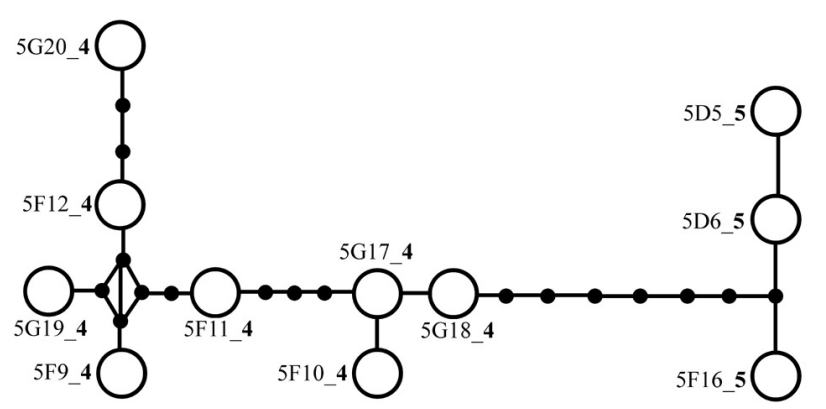

Fig. 28. Haplotype networks for COI, populations 4 and 5, connection limit excluding homoplastic changes set to $95 \%$; haplotype labels as in cladogram

all the Pseudamnicola and Adrioinsulana was rather highly (78) supported. Fig. 29 shows that populations 1-3 form well supported clades each, the Italian Pseudamnicola lucensis being the sister clade to population 1 . This grouping is not well supported $(<50)$; the same concerns the placement of $P$. negropontina from the Evvoia Island as the sister clade to the clade grouping all the specimens from populations 4 and 5, shown in Fig. 29. Like in the haplotype networks (Fig. 28), the greatest differences are seen in these two populations. 


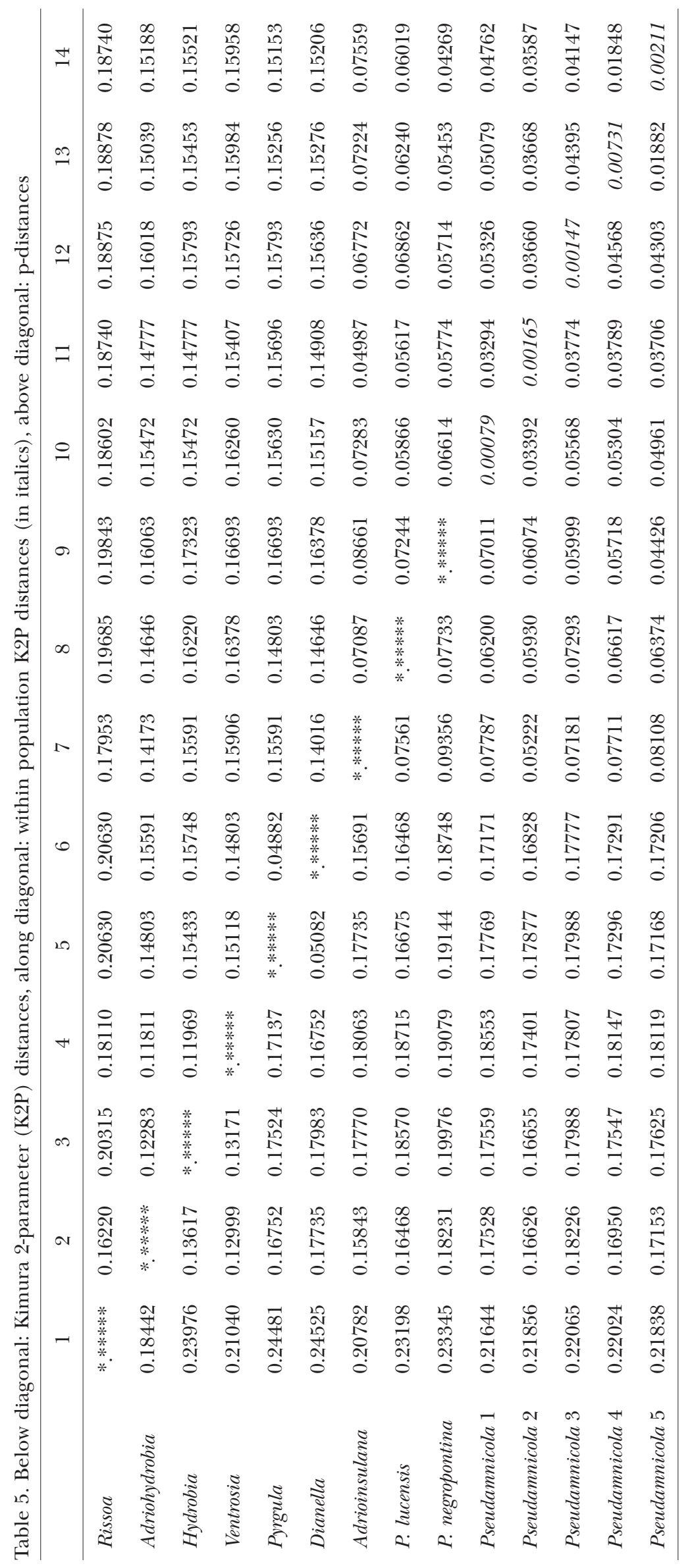




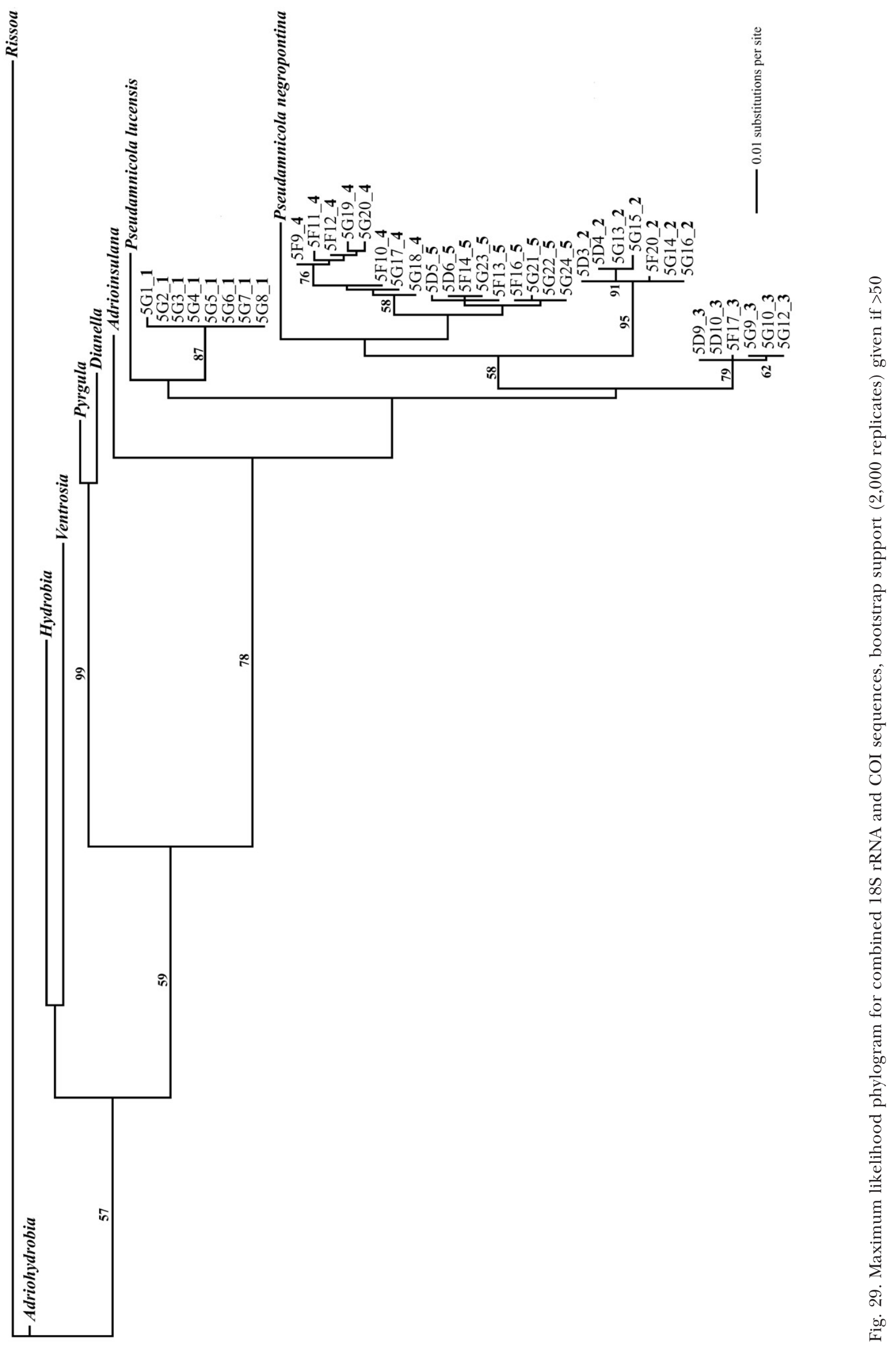




\section{DISCUSSION}

The studied shells resembled those of typical Pseudamnicola (BOETERS 1971, GIUSTI \& PEZZOLI 1980, SCHÜTT 1980, SZAROWSKA et al. 2006). Within the Rissooidea, shell characters are very variable and need not differ among species (FALNIOWSKI 1987, 1990, WILKE \& FALNIOWSKI 2001, SZAROWSKA \& WILKE 2004, FALNIOWSKI et al. 2009). In the studied populations, the penis and female reproductive organs did not differ from those of typical Pseudamnicola known from the literature (BOETERS 1971, 1998, RADOMAN 1973, 1978, 1983, GIUSTI \& PEZZOLI 1980, SCHÜTT 1980, SZAROWSKA 2006, SZAROWSKA et al. 2006). Contrary to rather common opinions expressed in the earlier studies (e.g. BOETERS 1973, see FALNIOWSKI 1990 for discussion), the anatomical characters (like the most often considered characters of the reproductive organs) need not differ among rissooid species (e.g. FALNIOWSKI et al. 2009). Morphostatic evolution, as defined by DAVIS (1992), is often a result of non-adaptive radiation marked by the rapid proliferation of species without ecological differentiation (GITTENBERGER 1991). This will produce a flock of species which are neither morphologically nor ecologically differentiated. Such may be the case of the studied Pseudamnicola. Although traditionally neglected, non-adaptive radiation seems to be not a rare phenomenon which occurs in gastropods (CAMERON 1992, CAMERON et al. 1996). SZAROWSKA (2006) and SZAROWSKA \& FALNIOWSKI (2008) demonstrated that, unexpectedly, the 'lock-and-key' mechanism is a stabilising factor above species level. Such structures as penis outgrowths and seminal receptacles/bursae copulatrix are thus conservative traits. Nevertheless, some details of their morphology that have been widely used in the species-level taxonomy, are prone to wide variation.

The high $h$ and low $\pi$, found in all five populations, may suggest a rapid population growth from an ancestral population with a small $N_{e}$, if time was sufficient for haplotype variation to recover through mutation, yet insufficient for large sequence differences to accumulate (AVISE 2000). Both $\theta_{\mathrm{S}}$ and $\theta_{\pi}$ suggest (assuming the same mutation rate $u$ in all the studied populations, which seems justified) that the evolutionarily effective population size was about three to five times larger in population 4 than in the other populations (since $\theta=2 N u$ for haploid data: EXCOFFIER et al. 2005). This contrasts with the low number of specimens found at this locality, which is due to the common instability of populations inhabiting springs (e.g. FALNIOWSKI et al. 1999, SZAROWSKA 2000, FALNIOWSKI et al. 2009).

In general, the observed pairwise values of $\mathrm{F}_{\mathrm{st}}$ and coancestry coefficient, as well as Nm, indicate low levels of gene flow in the studied Pseudamnicola. The low values of $\mathrm{F}_{\mathrm{st}}$ and coancestry coefficient (and the high values of $\mathrm{Nm}$ ) were found between populations 4 and 5, but the lowest (and highest, respectively) values were noted between populations 2 and 4 . In the former case the two localities in Kithira (4 and 5) were situated close to each other, whereas locality 2, situated at SE. Peloponnese was geographically distant from locality 4 and separated from it by the sea. This indicates once more that estimates of gene flow based on the analytic theory are not in all cases realistic (for discussion see FALNIOWSKI et al. 1999, 2002, 2004, FALNIOWSKI \& SZAROWSKA 2004).

The pattern shown by mismatch distribution in population 4 may reflect a bottleneck followed by a population growth (e.g. ROGERS \& JORDEY 1995, HARPENDING \& ROGERS 2000). In fact, in the huge complex of springs at Karavas, the size of which was not compared with any of the other four studied springs, the number of individuals was relatively low but they represented as many as eight haplotypes.

The values of K2P interpopulation distances are characteristic rather of congeneric distinct species (BICHAIN et al. 2007, FALNIOWSKI et al. 2007, SZAROWSKA et al. 2007, FALNIOWSKI et al. 2009). However, these values are relatively low for pairs of distinct species.

The monophyly of the clade Pseudamnicola/Adrioinsulana was confirmed, and Adrioinsulana should rather be included in Pseudamnicola, as suggested by SzAROWSKA et al. (2006). Again, the Italian P. lucensis is congeneric with the Greek Pseudamnicola. According to SCHÜTT (1980), the southern part of Peloponnese is inhabited by $P$. exilis. However, based on the K2P distances, as well as the inferred phylogeny, our five populations certainly do not represent one species. However, we can hardly answer the question: how many species are represented by the studied populations? Most probably we deal with a part of a flock of allopatric species which are morphologically and ecologically uniform (as suggested above). In such a case it is not easy to make decisions concerning taxonomy. Unfortunately, the majority of this flock probably do not exist any longer because of human impact and habitat destruction in Greece (SZAROWSKA \& FALNIOWSKI 2004), thus we can hardly expect much more data to support our understanding of this pattern. It is evident that population 1 from the Taigetos Mts can be regarded as a distinct species. According to SCHÜTT (1980), the lectotypes of P. exilis were collected in Lakonia, thus population 1 should be classified as $P$. exilis (Frauenfeld, 1863). Most probably, population 3 from Nisis Sfondi represents another distinct species. The two populations from Kithira (4 and 5) may represent a third, highly polymorphic species, which is close to $P$. negropontina. Population 2 from Nisis Monemvasia is probably a fourth distinct species. 


\section{ACKNOWLEDGEMENTS}

The study was supported by a grant from the Polish Ministry of Science and Higher Education (PB 2443/P01/2006/31) to ANDRZEJ FALNIOWSKI.

\section{REFERENCES}

AKAIKE H. 1974. A new look at the statistical model identification. IEEE Trans. Automatic Control 19: 716-723.

AVISE J. C. 2000. Phylogeography. The history and formation of species. Harvard University Press, Cambridge, MA and London.

Bichain J.-M., Gaubert P., SAmadi S., Boisselier-Dubayle M.-C. 2007. A gleam in the dark: phylogenetic species delimitation in the confusing spring-snail genus Bythinella Moquin-Tandon, 1856 (Gastropoda: Rissooidea: Amnicolidae). Mol. Phyl. Evol. 45: 927-941.

Boeters H. D. 1971. Pseudamnicola Paulucci, 1878 und Mercuria n. gen. (Prosobranchia, Hydrobiidae). Arch. Moll. 101: 175-181.

Boeters H. D. 1973. Die Gattung Bythinella and Gattung Marstoniopsis in Westeuropa, 1. Westeuropäische Hydrobiidae, 4 (Prosobranchia). Proc. Fourth Europ. Malac. Congr., Malacologia 14: 271-285.

BoETers H. D. 1998. Mollusca: Gastropoda: Superfamilie Rissooidea. In: Schwoerbel J., Zwick P. (eds), Süsswasserfauna von Mitteleuropa. 5/1-2, Gustav Fischer Verlag, Jena-Lübeck-Ulm, p. 76.

Butot L. J. M., WeLTER-Schultes F.W. 1994. Bibliography of the mollusc fauna of Greece, 1758-1994. Schr. Malakozool. Cismar 7: 1-160.

CAmeron R. A. D. 1992. Land snail faunas of the Napier and Oscar ranges, Western Australia: diversity, distribution and speciation. Biol. J. Linn. Soc. London 45: 271-286.

Cameron R. A. D., CoOK L. M., Hallows J. D. 1996. Land snails on Porto-Santo: adaptive and non adaptive radiation. Phil. Trans. Royal Soc. London B 351: 309-327.

Clement M., Posada D., CRANDAll K. A. 2000. TCS: a computer program to estimate gene genealogies. Mol. Ecol. 9: 1657-1660.

DAVIS G. M. 1992. Evolution of prosobranch snails transmitting Asian Schistosoma: coevolution with Schistosoma: a review. Prog. Clin. Parasitol. 3: 145-204.

EXCOFFIER L. 2004. Patterns of DNA sequence diversity and genetic structure after a range expansion: lessons from the infinite-island model. Mol. Ecol. 13: 853-864.

ExCOFfier L., LAVAl G., SCHNeIder S. 2005. Arlequin ver. 3.0: An integrated software package for population genetics data analysis. Evol. Bioinf. Online 1: 47-50.

Excoffier L., SMOUSE P., QUATTRO J. 1992 Analysis of molecular variance inferred from metric distances among DNA haplotypes: Application to human mitochondrial DNA restriction data. Genetics 131: 479-491.

FAlNiOWSKI A. 1987. Hydrobioidea of Poland (Prosobranchia: Gastropoda). Folia Malacol. 1: 1-122.

FALNIOWSKI A. 1990. Anatomical characters and SEM structure of radula and shell in the species-level taxonomy of freshwater prosobranchs (Mollusca: Gastropoda: Prosobranchia): a comparative usefulness study. Folia Malacol. 4: 53-142.

FAlniowski A., Heller J., MaZan-Mamczarz K., SZARowSKA M. 2002. Genetic structure of the closely related species of Melanopsis (Gastropoda: Cerithiacea) in Israel. J. Zool. Syst. Evol. Res. 40: 92-104.

FALNiOWSki A., MAZAN K., SZAROWSKa M. 1999. Homozygote excess and gene flow in the spring snail Bythinella (Gastropoda: Prosobranchia). J. Zool. Syst. Evol. Res. 37: $165-175$.

FALNiOWSKi A., SzAROWSKA M. 1995a. Can poorly understood new characters support a poorly understood phylogeny? Shell structure data in hydrobiid systematics (Mollusca: Gastropoda: Prosobranchia: Hydrobiidae). J. Zool. Syst. Evol. Res. 33: 133-144.

FALNIOWSKI A., SZAROWSKA M. 1995b. Shell SEM outer and inner structure and rissoacean phylogeny. V. Pseudamnicola cf. moussoni (Calcara) (Prosobranchia: Rissoacea: Hydrobiidae). Malak. Abh. 17: 173-180.

FALNIOWSKi A., SZAROWSKA M. 2004. Gene flow and differences among local populations of the land snail Arianta arbustorum (Linnaeus, 1758) (Pulmonata: Helicidae). Folia Malacol. 12: 157-171.

FALniowski A., SZArowska M., GRZMIL P. 2007. Daphniola Radoman, 1973 (Gastropoda: Hydrobiidae): shell biometry, mtDNA, and the Pliocene flooding. J. Nat. Hist. 41: 2301-2311.

FALNiOWSki A., SzAROWSKA M., SIRBU I. 2009. Bythinella Moquin-Tandon, 1856 (Gastropoda: Rissooidea: Bythinellidae) in Romania: species richness in a glacial refugium. J. Nat. Hist. 43: 2955-2973.

FALNiOWSKi A., SZAROWSKA M., WitKowskA-PELC E. 2004. Intra- and interpopulation genetic differentiation and gene flow in a group of isolated populations of Bradybaena fruticum (O. F. Müller, 1774) in South Poland. J. Zool. Syst. Evol. Res. 42: 70-80.

FARris J. S., Källersjö M., Kluge A. G., Bult C. 1995. Testing significance of incongruence. Cladistics 10: 315-319.

FELSENSTEIN J. 1985. Confidence limits on phylogenies: an approach using the bootstrap. Evolution 39: 783-791.

Folmer O., Black M., HOEH W., LUtZ R. A., VRIJENHOEK R. C. 1994. DNA primers for amplification of mitochondrial cytochrome c oxidase subunit I from diverse metazoan invertebrates. Mol. Mar. Biol. Biotechnol. 3: 294-299.

GARrick R. C., DYer R. J., Beheregaray L. B., SUNNUCKS P. 2008. Babies and bathwater: a comment on the premature obituary for nested clade phylogeographical analysis. Mol. Ecol. 17: 1401-1403. 
GITTENBERGER E. 1991. What about non-adaptive radiation? Biol. J. Linn. Soc. 43: 263-272.

GiUsti F., Pezzoli E. 1980. Gasteropodi, 2 (Gastropoda: Prosobranchia: Hydrobioidea, Pyrguloidea). Consiglio Nazionale delle Ricerche AQ/1/47. Guide per il riconoscimento delle specie animali delle acque interne Italiane, 8, Verona.

GLÖER P. 2002. Die Süsswassergastropoden Nord- und Mitteleuropas. Bestimmungsschlüssel, Lebensweise, Verbreitung. Die Tierwelt Deutschlands, 73, Mollusca I. Conch-Books, Hackenheim.

HALL T. A. 1999. BioEdit: a user-friendly biological sequence alignment editor and analysis program for Windows 95/98/NT. Nucl. Acids Symp. Ser. 41: 95-98.

HARPENDING H. 1994. Signature of ancient population growth in a low-resolution mitochondrial DNA mismatch distribution. Human Biol. 66: 591-600.

HARPENDING H., Rogers A. R. 2000. Genetic perspectives on human origins and differentiation. Annu. Rev. Genom. Human Genet. 1: 361-85.

Hillis D. M., MABle B. K., LARSON A., DAVIS S. K., ZimMER E. A. 1996. Nucleic acids IV: Sequencing and Cloning. In: Hillis D. M., Moritz C., MABLE B. K. (eds.). Molecular Systematics. Second Edition. Sinauer Associates Inc. Publishers, Sunderland, Massachusetts, pp. 321-381.

KABAT A. R., HERSHLER R. 1993. The prosobranch snail family hydrobiidae (Gastropoda: Rissooidea): review of classification and supraspecific taxa. Smiths. Contr. Zool. 547: 1-94.

KIMURA M. 1980. A simple method for estimating evolutionary rate of base substitutions through comparative studies of nucleotide sequences. J. Mol. Evol. 16: 111-120.

KNOWLES L. L., MADDISON W. P. 2002. Statistical phylogeography. Mol. Ecol. 11: 2623-2635.

MADDISON D. R., MADDISON W. P. 2002. MACCLADE. Ver. 4.05. [Computer software and manual]. Sinauer Associates Inc. Publishers, Sunderland, Massachusetts.

PAlumbi S. R. 1996. Nucleic Acids II: The Polymerase Chain Reaction. In: Hillis D. M., MORITZ C., MABle B. K. (eds), Molecular Systematics. Second Edition, Sinauer Associates Inc. Publishers, Sunderland. Massachusetts, pp. 205-247.

PANCHAL M. 2007. The automation of nested clade phylogeographic analysis. Bioinformatics 23: 509-510.

PANCHAL M., BEAUMONT M. A. 2007. The automation and evaluation of nested clade phylogeographic analysis. Evolution 61: 1466-1480.

PETIT R. J. 2007. The coup de grace for the nested clade phylogeographic analysis? Mol. Ecol. 17: 516-518.

PETIT R. J. 2008. On the falsifiability of the nested clade phylogeographic analysis method. Mol. Ecol. 17: 1404-1404.

POSADA D. 2003. Selecting models of evolution. In: SALEMI M., VANDAMME A.-M. (eds). The phylogenetic handbook. A practical approach to DNA and protein phylogeny. Cambridge University Press, Cambridge, pp. 256-282.

POSADA D., BUCKLEY T. R. 2004. Model selection and model averaging in phylogenetics: advantages of Akaike Infor- mation Criterion and Bayesian approaches over Likelihood Ratio Tests. Syst. Biol. 53: 793-808.

PosadA D., Crandall K. A. 1998. Modeltest: testing the model of DNA substitution. Bioinformatics 14: 817-818.

Posada D., Crandall K. A., Templeton A. R. 2000. GeoDis: a program for the cladistic nested analysis of the geographical distribution of genetic haplotypes. Mol. Ecol. 9: 487-488.

Radoman P. 1972. Nochmals über die Gattung Pseudamnicola und schliesslich die Gattung Orientalina n. gen. Arch. Moll. 102: 195-200.

RADOMAN P. 1973. New classification of fresh and brackish water Prosobranchia from the Balkans and Asia Minor. Posebna Izd. Prir. Muz. Beograd 32: 1-30.

RADOMAN P. 1978. Beispiele der mikrogeographischen Speciation in Ohrid-See und die neue Gattung Adrioinsulana. Arch. Moll. 109: 45-50.

RADOMAN P. 1983. Hydrobioidea a superfamily of Prosobranchia (Gastropoda). I. Systematics. Serbian Academy of Sciences and Arts. Monographs 547, Department of Sciences 57: 1-256.

RADOMAN P. 1985. Hydrobioidea, a superfamily of prosobranchia (Gastropoda). II. Origin, zoogeography, evolution in the Balkans and Asia Minor. Faculty of Science Department of Biology Monographs, 1, Institute of Zoology Beograd 1: 1-173.

REYNOLDS J., WEIR B. S., COCKERHAM C. C. 1983. Estimation for the coancestry coefficient: basis for a short-term genetic distance. Genetics 105: 767-779.

Rogers A. R. 1995. Genetic evidence for a Pleistocene population explosion. Evolution 49: 608-615.

Rogers A. R., HARPENDING H. 1992. Population growth makes waves in the distribution of pairwise differences. Mol. Biol. Evol. 9: 552-569.

RoGers A. R., JORDEY L. B. 1995. Genetic evidence on modern human origins. Human Biol. 67: 1-36.

Rozas J., SÁNChez-Delbarrio J. C., Messeguer X., RoZas R. 2003. DnaSP, DNA polymorphism analyses by the coalescent and other methods. Bioinformatics 19: 2496-2497.

SCHNEIDER S., EXCOFFIER L. 1999. Estimation of demographic parameters from the distribution of pairwise differences when the mutation rates vary among sites: Application to human mitochondrial DNA. Genetics 152: 1079-1089.

SCHÜTT H. 1980. Zur Kenntnis griechischer Hydrobiiden. Arch. Moll. 110: 115-149.

SOBER E. 2002. Instrumentalism, parsimony, and the Akaike framework. Phil. Sci. 69: 112-123.

SWOFFORD D. L. 2002. PAUP*. Phylogenetic analysis using parsimony (*and other methods). Version 4. Sinauer Associates Inc. Publishers, Sunderland, Massachusetts.

SWOFFORD D. L., Olsen G. J., WAdDell P. J., Hillis D. M. 1996. Phylogenetic inference. In: HILLIS D. M., MORITZ C., MABLE B. K. (eds), Molecular systematics. Second Edition. Sinauer Associates Inc. Publishers, Sunderland, Massachusetts, pp. 407-514. 
SZAROWSKA M. 2000. Environmental stress and stability of Bythinella populations in South Poland (Gastropoda: Prosobranchia: Hydrobioidea). Malak. Abh. 20: 93-98.

SZAROWSKA M. 2006. Molecular phylogeny, systematics and morphological character evolution in the Balkan Rissooidea (Caenogastropoda). Folia Malacol. 14: 99-168.

SZAROWSKA M., FALNIOWSKI A. 2004. "Hydrobioid" localities in Greece: an urgent case for conservation. Tentacle 12: $14-15$.

SZAROWSKA M., FALNIOWSKI A. 2008. There is no philosopher's stone: coup de grace to the morphology-based systematics in the rissooidean gastropods? Abstracts, 5th Congress of the European Malacological Societies 2nd AINIC. Atlantic Islands Neogene, International Congress, 2-6 September 2008, Ponta Delgada, Azores, Portugal: 28.

SZAROWSKa M., FALNIOWSKI A., Riedel F., Wilke T. 2005. Phylogenetic relationships of the subfamily Pyrgulinae (Gastropoda: Caenogastropoda: Hydrobiidae) with emphasis on the genus Dianella Gude, 1913. Zootaxa 891: $1-32$.

SZAROwSKA M., GrZMIL P., FALNIOWSKI A. 2006. Pseudamnicola Paulucci, 1878 (Gastropoda: Hydrobiidae) in the Balkans. Folia Malacol. 14: 179-190.

SZAROWska M., GRZMIL P., FALNiOWSKI A., SiRbU I. 2007. Grossuana codreanui (Grossu, 1946) and the phylogenetic relationships of the East Balkan genus Grossuana (Radoman, 1973) (Gastropoda: Rissooidea). Hydrobiologia 579: 379-391.

SZAROWSKA M., WiLke T. 2004. Sadleriana pannonica (Frauenfeld, 1865): a lithoglyphid, hydrobiid or amnicolid taxon? J. Moll. Stud. 70: 49-57.

TAJIMA F. 1983. Evolutionary relationship of DNA sequences in finite populations. Genetics 105: 437-460.

TAJIMA F. 1989. The effect of change in population size on DNA polymorphism. Genetics 123: 597-601.

TEMPLETON A. R. 2008. Nested clade analysis: an extensively validated method for strong phylogeographic inference. Mol. Ecol. 17: 1877-1880.

Templeton A. R., Boerwinkle E., Sing C. F. 1987. A cladistic analysis of phenotypic associations with haplotypes inferred from restriction endonuclease mapping. 1. Basic theory and an analysis of alcohol dehydrogenase activity in drosophila. Genetics 117: 343-351.

Templeton A. R., Crandall K. A., Sing C. F. 1992. A cladistic analysis of phenotypic associations with haplotypes inferred from restriction endonuclease map- ping and DNA sequence data. 3. Cladogram estimation. Genetics 132: 619-633.

Templeton A. R., Sing C. F. 1993. A cladistic analysis of phenotypic associations with haplotypes inferred from restriction endonuclease mapping. 4. Nested analyses with cladogram uncertainty and recombination. Genetics 134: 659-669.

THIELE J. 1929. Handbuch der systematischen Weichtierkunde. Erster Band, Teil 1. Gustav Fischer Verlag, Jena.

ThOMPSOn J. D., Gibson, T. J., Plewniak F., JeAnMougin F., HigGINS D. G. 1997. The CLUSTALX windows interface: flexible strategies for multiple sequence alignment aided by quality analysis tools. Nucl. Acids Res. 24: 4876-4882.

WAGNER A. 1927. Studien zur Molluskenfauna der Balkanhalbinsel mit besonderer Berücksichtigung Bulgariens und Thraziens, nebst monographischer Bearbeitung einzelner Gruppen. Ann. Zool. 6: 263-399.

WATTERSON G. 1975. On the number of segregating sites in genetical models without recombination. Theor. Popul. Biol. 7: 256-276.

WEIR B. S. 1996. Genetic data analysis II: methods for discrete population genetic data. Sinauer Associates Inc. Publishers, Sunderland, Massachusetts.

WILKE T., DAVIS G. M. 2000. Infraspecific mitochondrial sequence diversity in Hydrobia ulvae and Hydrobia ventrosa (Hydrobiidae: Rissoacea: Gastropoda): Do their different life histories affect biogeographic patterns and gene flow? Biol. J. Linn. Soc. London 70: 89-105.

Wilke T., DAVIS G. M., FALNiOWSKI A., GIUSTI F., BODON M., SZAROWSKA M. 2001. Molecular systematics of Hydrobiidae (Gastropoda: Rissooidea): testing monophyly and phylogenetic relationships. Proc. Acad. Nat. Sci. Philadelphia 151: 1-21.

WiLkE T., FALNIOWSKI A. 2001. The genus Adriohydrobia (Hydrobiidae: Gastropoda): polytypic species or polymorphic populations? J. Zool. Syst. Evol. Res. 39: 227-234.

XIA X. 2000. DAMBE 4.0 (Software Package for Data Analysis in Molecular Biology and Evolution). University of Hongkong, Department of Ecology and Biodiversity, Hong Kong.

Xia X., Xie Z., SAlemi M., Chen L., Wang Y. 2003. An index of substitution saturation and its application. Mol. Phyl. Evol. 26: 1-7.

Received: January 24th, 2011

Accepted: February 23rd, 2011 